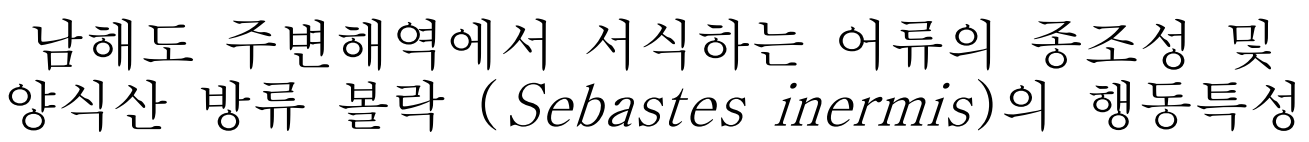

\author{
안철민·곽석남 ${ }^{*} \cdot$ 박주면 $^{2} \cdot$ 허성회 $^{2}$ \\ 국립수산과학원 전략양식연구소 생명공학과, \\ 1해양생태기술연구소, ${ }^{2}$ 부경대학교 해양학과
}

\title{
Species Composition and Behavioral Characteristics of Released Black Rockfish, Sebastes inermis in the Coastal Waters off Namhae Island, Korea
}

\author{
Cheul Min An, Seok Nam Kwak ${ }^{1 *}$, Joo Myun Park², \\ and Sung-Hoi Huh ${ }^{2}$ \\ Biotechnology Research Division, National Fisheries Research \& \\ Development Institute, Busan 619-705, Korea \\ ${ }^{1}$ Marine Eco-Technology Institute Co., Ltd., Busan 608-830, Korea \\ ${ }^{2}$ Department of Oceanography, Pukyong National University, \\ Busan 608-737, Korea
}

\begin{abstract}
Seventeen fish species were counted in an underwater visual census, and the most common species, Sebastes inermis and Halichoeres poecilopterus, were released. More than $60 \%$ of the released S.inermis occurred near a fish farm 5 days after release, but they moved to a distant rocky area, and decreasing numbers were seen near the farm 90 days after release. In pots, a total of 722 individuals belonging to 43 species occurred, and released S.inermis dominated with 174 individuals recaptured during the study period. The other common fish species were Stephanolepis cirrhifer and Acanthopagrus schlegeli. The percentage of recapture was $0.23 \%$, but declined to $0.12 \%$ at 90 days after release. The potential predators of released S.inermis included Lateolabrax japonicus and Sebastes schlegeli.
\end{abstract}

Key words: Released Sebastes inermis, Species composition, Behavioral characteristics

\section{서 론}

수중잠수조사 (underwater visual census, UVC)에 의한 해양 생물 군집조사 방법 (직접 기록, 사진 및 비디오 영상 분석)은 생태계를 교란시키지 않고, 직접 채집의 방법으로 조사하기 어려운 생물의 출현량 변동 및 생태적 특성을 조사하기에 유용하다 (Samoilys, 1997; Tessier et al., 2005). 이 방법은 전적 으로 사람의 시력에 의한 관찰에 의존하기 때문에 생물의 크기, 행동, 시야를 방해해는 요인 (빛의 양, 부유물질 등) 등이 제한요소로 작용할 수 있지만, 표지 방류한 어류의 행동 및 생태적 특성을 밝히는데 유용하게 이용될 수 있다 (Morinière et al., 2004; Edgar et al., 2004; Meynecke et al., 2008).

본 연구의 대상 어종인 볼락 (Sebastes inermis)은 쏨뱅이목 (Order Scorpaeniformes) 양볼락과 (Family Scorpaenidae)에 속 하는 어류로, 암초가 많은 연안해역에 주로 서식하는 연안정착 성 어류이다 (NFRDI, 2004). 볼락은 국내에서 수산자원 증대를 위한 수산생물 종묘 방류사업의 중요한 대상 품종 중 하나로 최근 들어 방류양이 증가하는 추세에 있으며 (MOMAF, 2004,

\footnotetext{
*Corresponding author: seoknam@hotmail.com
}

2006; NFRDI, 2007), 진해 잠도 주변해역에서 방류산 볼락의 식성 연구에서 방류산 볼락의 섭식적응 상태를 보고한 바 있다 (Kim et al., 2009).

성공적인 수산자원 종묘 방류사업의 결과를 도출하기 위해 서는 방류품종이 방류해역의 환경에 적응하여 유용 수산자원 으로 가입하는 기작을 밝히는 것이 중요하다. 특히 적절한 방류 시기, 방류량, 방류 개체 크기의 선정은 성공적인 방류사 업을 위한 중요한 요소들이다 (Tanaka et al., 2006). 방류지역에 서 방류 품종의 생존은 각 개체의 영양상태와 같은 생리적인 현상과 피식-포식 관계, 먹이 이용가능성 등의 외부적인 요인 에 의하여 영향을 받을 수 있다. 특히 방류품종의 굶주림에 의한 낮은 성장의 결과는 포식자에 의한 높은 피식의 결과를 가져오게 되는 것이다 (Bailey and Houde, 1989; Gamble and Hay, 1989; Yamashita et al., 1994). 따라서 방류품종의 방류 후 초기 행동특성, 어류군집 및 피식-포식관계의 연구는 방류 해역에서 방류개체의 적응 정도와 생존 과정을 밝히는데 중요 한 자료를 제공할 수 있다.

본 연구는 경상남도 남해도 주변해역에서 방류한 양식산 방류 볼락이 서식하는 서식처 주변해역의 어류의 종조성 및 방류 볼락의 방류 후 행동특성을 파악하고자 한다. 


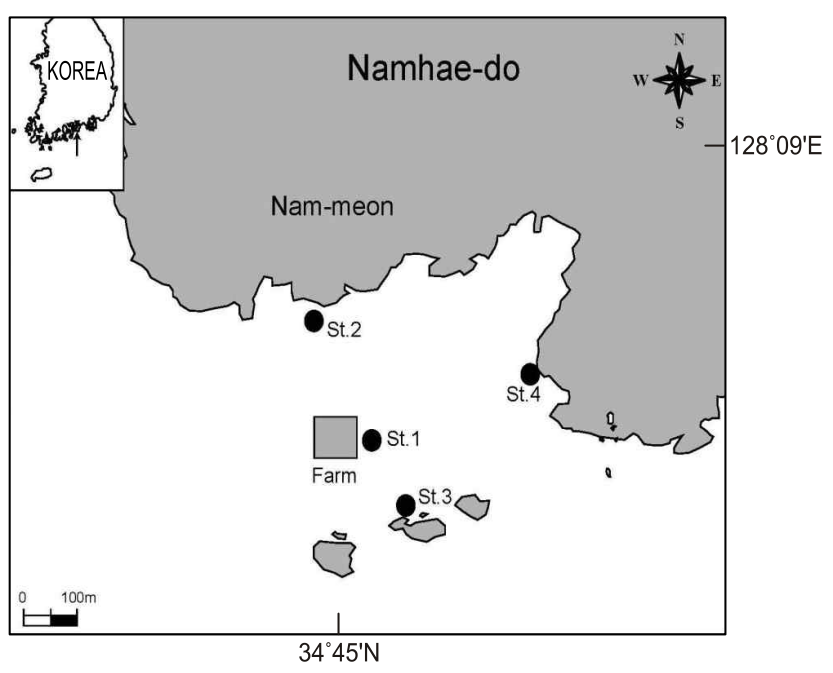

Fig. 1. Location of the study area.

\section{재료 및 방법}

본 연구에 사용된 양식산 방류 볼락의 시료는 경상남도 수산자원연구소에서 인공종묘 생산되어 2 3개월 정도 사육 한 30,000 개체 (5.6 7.2 cm TL)를 방류 전에 표지 또는 배지느 러미 절단 후 경상남도 남해도 남면 주변해역에 위치한 가두 리에서 방류환경에 적응시키기 위하여 5일간 먹이공급을 중 단하고 순치하였다 (Fig. 1). 순치가 끝난 후 2008년 8월에 수중에서 가두리를 개방하여 양식산 볼락을 방류하였다. 방류 해역 주변 어류의 종조성 및 방류 볼락의 행동 특성 조사는
2008년 8월에서 12월까지 방류 지점을 중심으로 수중잠수조 사 및 연안 통발을 이용하였다. 수중잠수조사는 조사해역을 line transect로 구분한 후, 이동식비디오를 이용하여 4개의 정 점에서 실시하였다. 정점 1 은 가두리 부근, 정점 2 는 가두리 북쪽 암반지역, 정점 3 은 가두리 남쪽 암초지역, 그리고 정점 4는 가두리 서쪽 암반지역이다. 수중 비디오 촬영은 방류 당일, 1일, 3일, 5일, 7일, 10일, 20일, 30일, 60일, 90일에 실시하여 양식산 방류 볼락의 방류 후 초기 행동특성을 중점적으로 파악 하였다. 수중 비디오 촬영결과는 각 종의 출현시간에 대한 백분율로 나타내었으며, 출현량 $(\mathrm{F})$ 는 다음과 같이 구하였다.

$$
F=\frac{T_{i}}{T_{\text {total }}} \times 100
$$

( $T_{i}$ : i종의 출현시간, $T_{\text {total }}$ : 비디오에 어류가 촬영된 총시간)

한편 어구를 이용한 조사에서는 주변지역에서 거주하고 하는 어민들의 상용어구인 연안통발을 이용하였다. 조사주기 는 방류 10 일, 20 일, 30 일, 60 일, 90 일에 실시하였다. 연안통발 은 길이 $100 \mathrm{~cm}$, 지름 $50 \mathrm{~cm}$, 망목 $1.5 \mathrm{~cm}$ 의 통발을 방류지점 주변에 50 개를 24 시간동안 설치한 뒤 어구를 수거하여 어류를 채집하였다. 채집된 어류는 채집 즉시 냉장 보관하여 실험실 로 운반한 뒤, Masuda et al. (1984), Yoon (2002) 등을 이용하여 분류 및 동정하였다. 각 종의 출현량은 개체수로 나타내었다. 방류산 볼락의 재채포율은 방류한 전체 개체수 $(30,000$ 개체 $)$ 에 대하여 채집된 개체수의 백분율로 산정하였다.

Table 1. Frequency of occurrence of fish species and released Sebastes inermis collected by underwater visual census in the study area

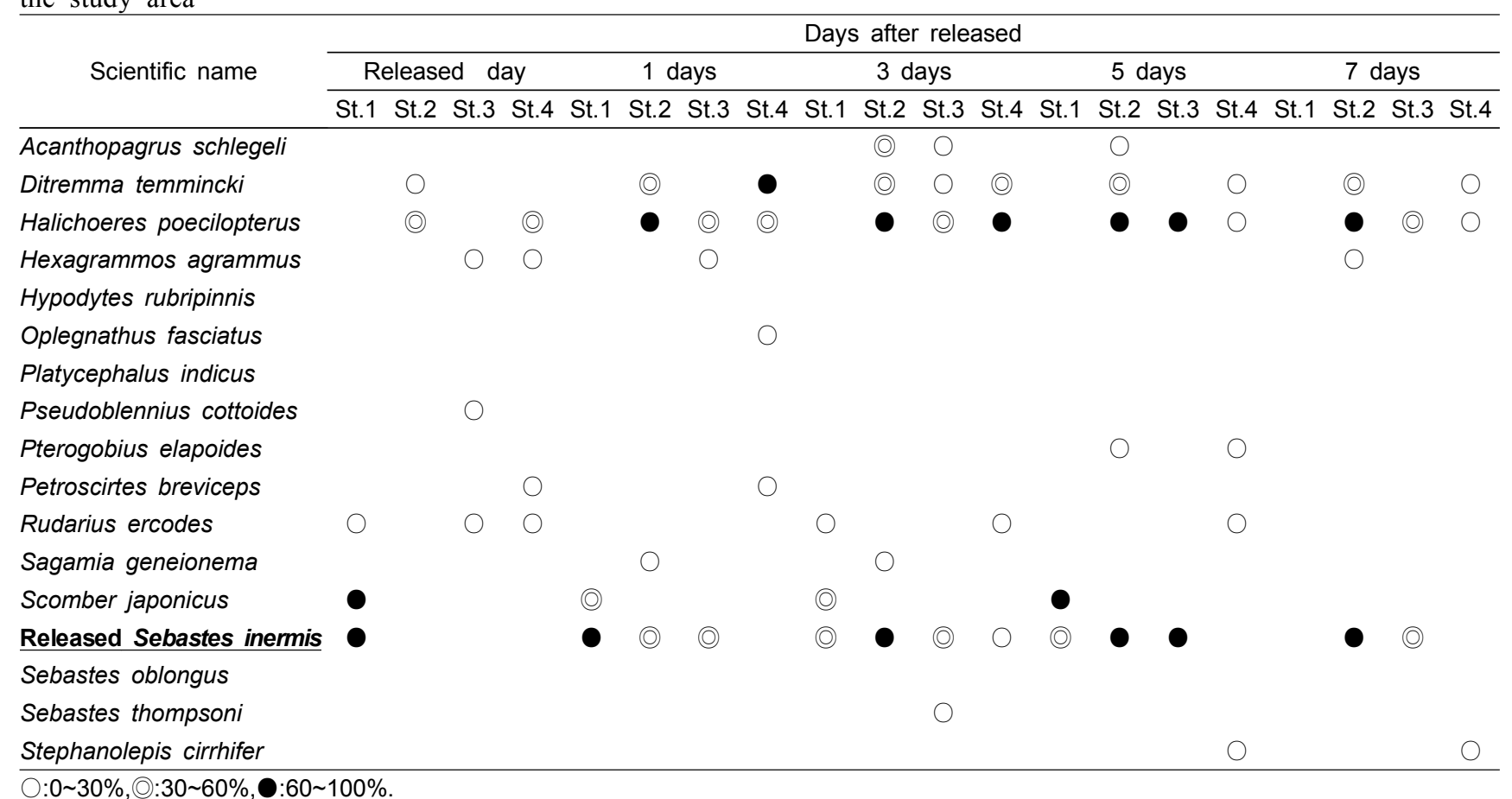

○:0 30\%,@:30 60\%,@:60 100\%. 
Table 1. (continued)

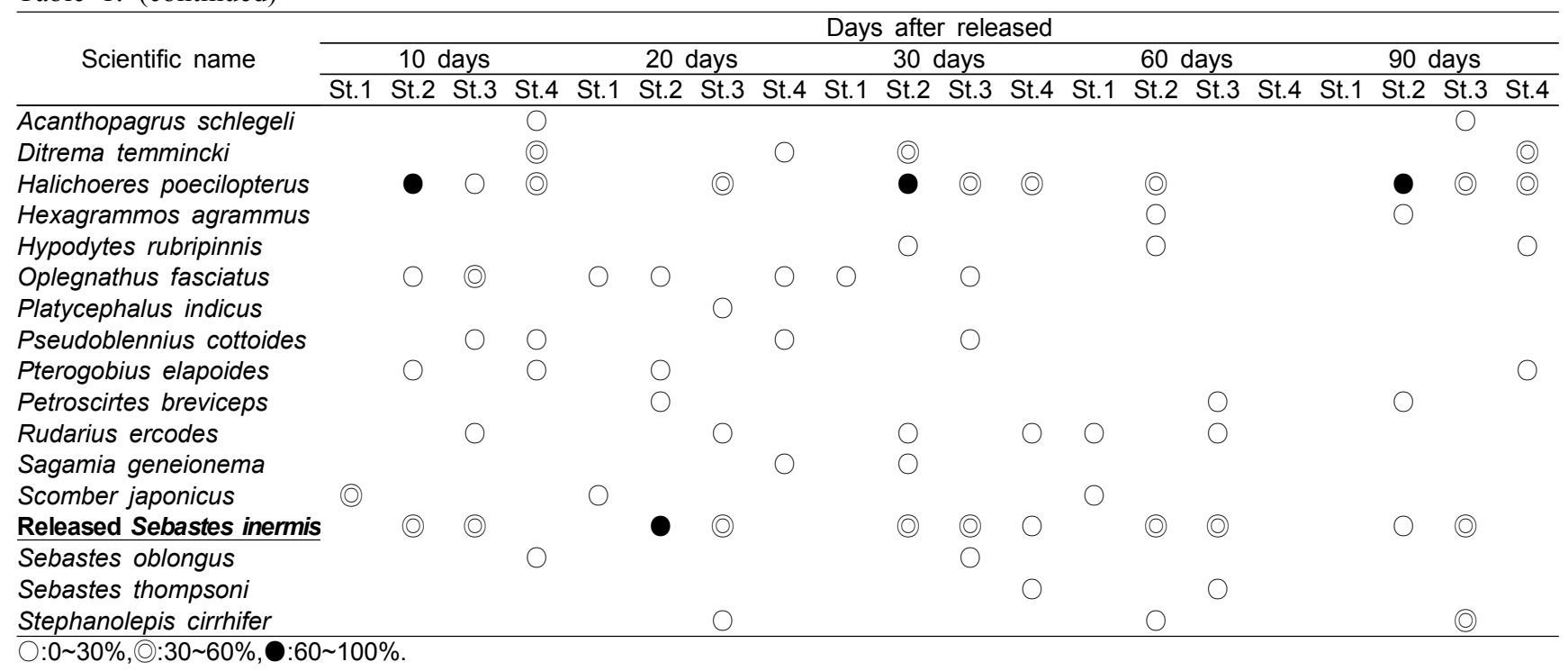

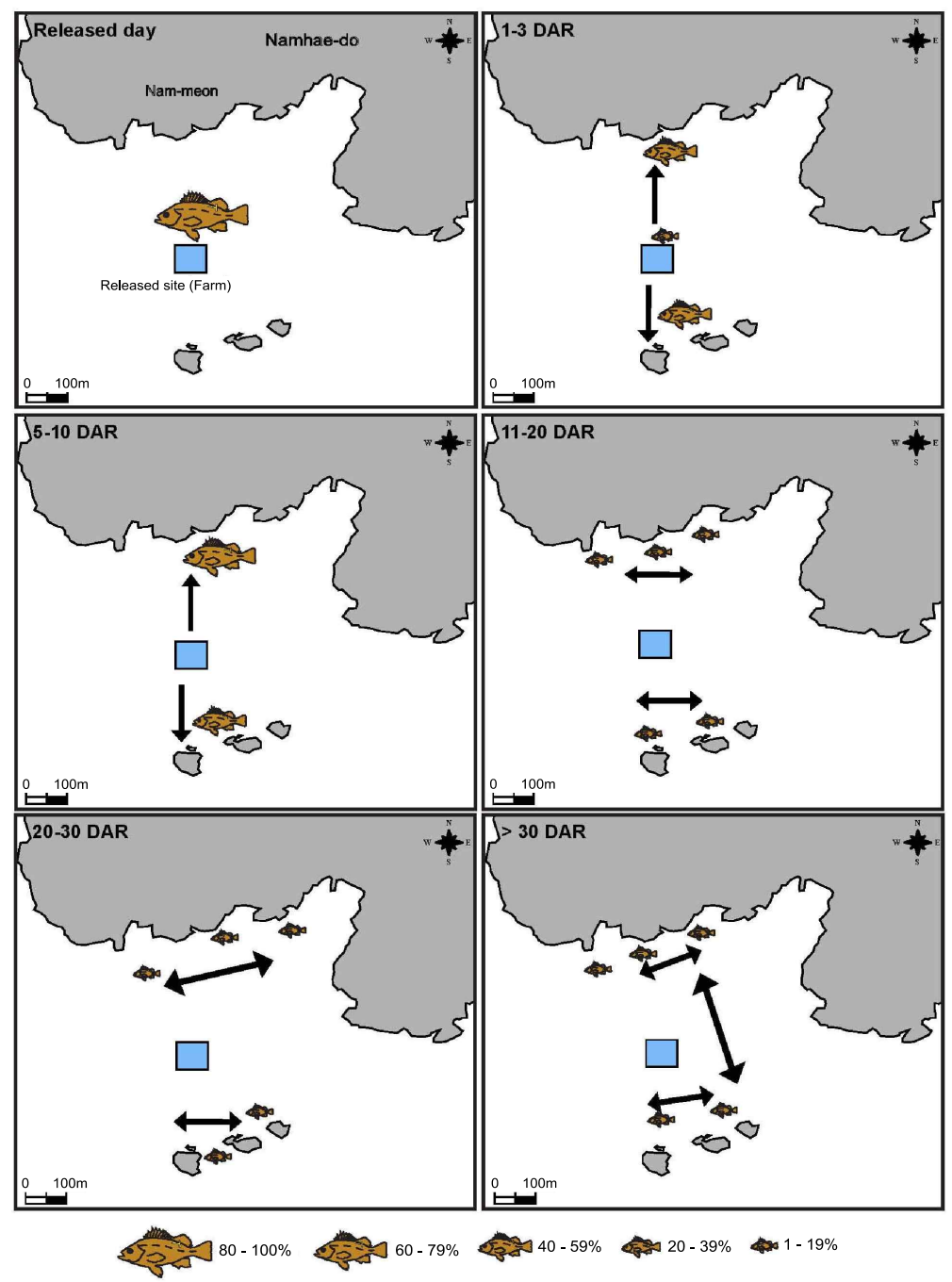

Fig. 2. Behavioral characteristics of released Sebastes inermis in the study area (DAR: Days after released). 

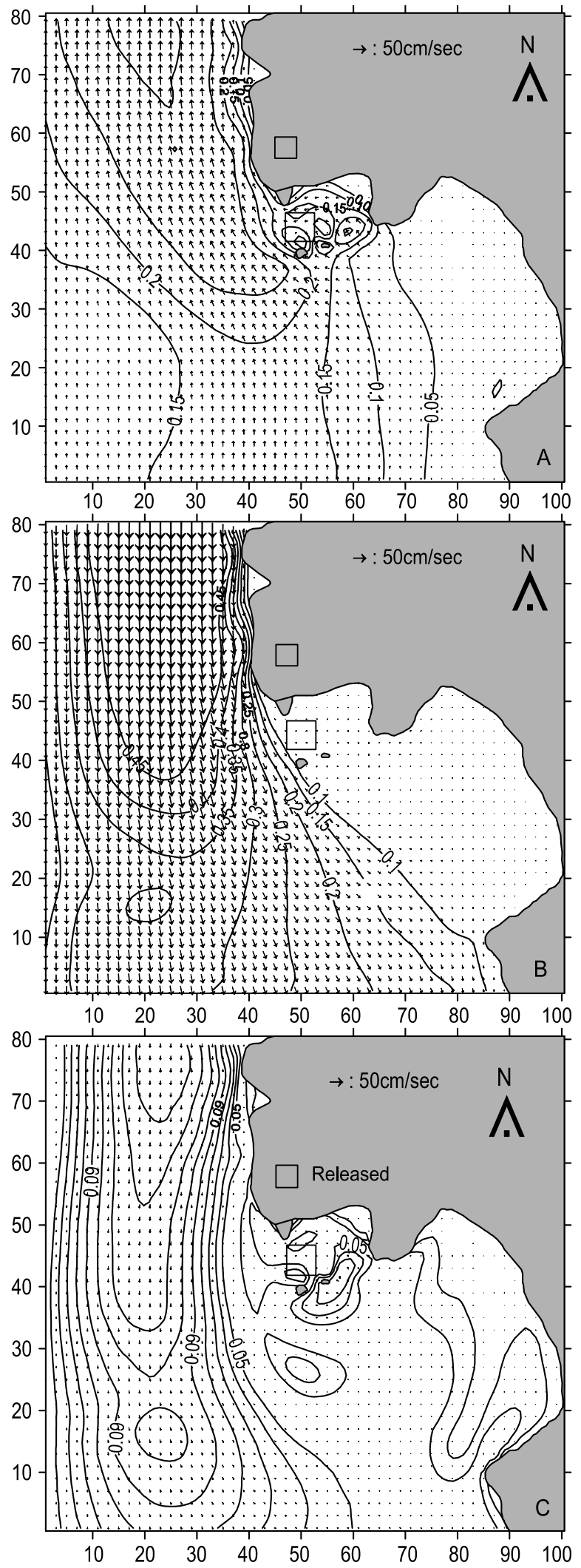

Fig. 3. Simulation of seawater movement in flood (A), ebb (B) and residual (C) current in the study area.
결과 및 고찰

\section{수중잠수조사}

조사기간 동안 총 17종의 어류가 출현하였다 (Table 1). 방류산 볼락 (Released Sebastes inermis)과 용치놀래기 (Halichoeres poecilopterus)가 가장 많이 출현하였으며, 그 외 가시망둑 (Pseudoblennius cottoides), 감성돔 (Acanthopagrus schlegeli), 고등어 (Scomber japonicus), 그물코쥐치 (Rudarius ercodes), 노래미 (Hexagrammos agrammus), 돌돔 (Oplegnathus fasciatus), 두줄베도라치 (Petroscirtes breviceps), 망상어 (Ditremma temmincki), 미역치 (Hypodytes rubripinnis), 바닥문 절 (Sagamia geneionema), 불볼락 (Sebastes thompsoni), 양태 (Platycephalus indicus), 일곱동갈망둑 (Pterogobius elapoides), 쥐치 (Stephanolepis cirrhifer), 황점볼락 (Sebastes oblongus) 등 총 17 종의 어류가 출현하였다.

방류산 볼락의 방류 후 행동특성을 살펴보면, 방류직후 방 류 볼락은 방류지점인 정점 1 의 가두리 그물 주변에서 $60 \%$ 이상의 높은 출현율을 보이면서 무리를 지어 표층에서 떠다니 고 있었으며, 그 외 정점에서는 발견되지 않았다 (Fig. 2). 방류 1 일째 방류산 볼락은 정점 1 에서 방류 당일과 비슷한 분포를 보였고, 정점 2 와 3 에서 방류산 볼락이 $30 \sim 60 \%$ 의 출현율을 보였고, 정점 4에서는 발견되지 않았다. 방류 3 일째와 5 일째 방류산 볼락은 정점 $1,2,3$ 에서 $30 \%$ 이상의 출현율을 보였으 며, 정점 4에서는 발견되지 않았다. 방류 7 일째 정점 1 에서는 방류산 볼락이 발견되지 않았고, 정점 2와 3 에서 $30 \%$ 이상을 출현율을 보이면서 발견되었다. 방류 7일째 이후 90 일째까지 방류산 볼락은 정점 2와 3에서만 발견되었으며, 시간이 지남 에 따라 출현율은 점점 감소하는 양상을 나타내었다. 따라서 본 조사에서 방류산 볼락은 방류 후 5 일째 까지 방류지점 가두리 주변에 서식하다가, 대부분 개체가 암반지역인 정점 2 와 3 근처로 이동하여 서식함을 알 수 있었고, 사질지역인 정점 4 에서는 발견되지 않았다.

방류산 볼락은 방류 후 암반 식물군락과 같이 선호하는 먹이생물이 풍부하고 몸을 숨길 수 있는 공간이 있는 서식지 를 찾아 이동한다고 보고되고 있다 (NFRDI, 2007). 그러나 방류산 볼락은 방류 초기에 볼락의 적정 서식지가 아닌 가두 리 주변에서 방류 5일째까지 서식하고 있었는데, 이는 오랫동 안 가두리에서 서식하던 습성이 남아 있었기 때문인 것으로 판단된다. 시간이 흐르면서 방류산 볼락은 적정 서식지인 인 근 정점 2와 3 으로 해류의 영향으로 이동하였을 것으로 추정 된다. 방류 주변 해역의 해수 유동 수치모델을 살펴보면 (Fig. $3)$, 창조시에는 남쪽에서 북쪽으로 낙조시에는 북쪽에서 남쪽 으로 흐르는 흐름패턴을 나타내었다. 한편 잔차류는 대조기에 는 방류 해역을 중심으로 $5 \mathrm{~cm} / \mathrm{sec}$ 이하의 북상하는 흐름이었 으나 다소 바깥쪽에 위치한 외양 해역에서는 큰 유속이 남하 하는 것으로 나타났다 (Fig. 3). 따라서 방류산 볼락의 방류 후 이동 및 행동특성은 주변해역의 해수 유동 패턴과 어느 정도 상관성이 있음을 알 수 있다.

방류산 볼락은 서식지에서 무리를 지어 큰 움직임 없이 
서식하면서 다양한 어류와 공존하는 현상을 보였는데, 가장 많이 출현한 어류는 용치놀래기였고 그 다음으로 망상어였다. 용치놀래기와 망상어는 많은 개체가 방류산 볼락 무리 주변에 서 유영하면서 서식하고 있었으나 방류산 볼락을 공격하는 행동은 보이지 않았다. 고등어의 경우 방류 후 가두리 주변에 서 높은 출현율을 보이면서 유영하고 있었으나, 방류 볼락 무리는 공격하거나 공존하는 현상은 보이지 않았다. 불볼락의 경우 1-2개체가 방류산 볼락 무리에 섞여 비슷한 행동양상을 보이면서 서식하고 있었고, 일곱동갈망둑의 경우 단독으로 유영하면서 방류산 볼락과 자연스럽게 공존하는 양상을 보였 다. 감성돔의 경우 방류산 볼락 무리 주변을 빠르게 왔다 갔다 하면서 종종 방류산 볼락을 공격하여 무리를 흩어버리는 행동 을 보이기도 하였다. 가시망둑의 경우 체장이 작거나 무리에 서 이탈한 방류산 볼락을 포식하는 현상을 보이기도 하였다.

\section{연안통발 조사}

조사기간 동안 총 43 종, 722 개체의 어류가 채집되었다 (Table 2). 개체수에서 우점한 어류를 살펴보면 방류산 볼락이 174 개체로 가장 우점하였으며, 그 다음으로 쥐치가 118 개체로 이들 두 종이 전체 채집개체수의 $40.4 \%$ 를 차지하였다. 그 다음 으로 용치놀래기, 자연산 볼락, 감성돔, 쥐노래미 (Haxagrammos otakii), 복섬 (Takifugu niphobles), 불볼락이 20 개체 이상 채집되어 우점하였다. 그 외 인상어 (Neoditrema ransonneti), 농어 (Lateolabrax japonicus), 흰꼬리볼락 (Sebastes longispinis), 붕장어 (Conger myriaster), 망상어, 돌돔, 그물코쥐 치, 노래미, 말쥐치 (Thamnaconus modestus), 문치가자미 (Pleuronectes yokohamae), 열동가리돔 (Apogon lineatus), 각시 서대 (Pseudaesopia japonica), 조피볼락 (Sebastes schlegeli), 쌍동가리 (Parapercis sexfasciata), 가시망둑, 미역치, 청보리멸 (Sillago japonica), 붉바리 (Epinephelus akaara), 범돔 (Microcanthus strigatus), 점농어 (Lateolabrax maculatus), 전어 (Konosirus punctatus), 전갱이 (Trachrus japonicus), 넙치 (Paralichthys olivaceus), 날돛양태 (Repomucenus beniteguri), 참가자미 (Pleuronectes herzensteini), 주홍감펭 (Scorpaenodes littoralis), 왜도라치 (Chirolophis wui), 양태, 숭어 (Mugil cephalus), 비단망둑 (Istigobius hoshinonis), 무점황놀래기 (Pseudolabrus eoethinus), 두줄베도라치, 독가시치 (Siganus fuscescens), 금줄촉수 (Parupeneus ciliatus) 그리고 홍감펭 (Helicolenus hilgendorfi) 순으로 출현하였다.

본 조사해역에서 연안통발에 의해 자연산과 방류산 볼락이 모두 채집되었으며, 방류산 볼락이 174 개체가 채집되어 전체 채집개체수의 $24.6 \%$ 를 차지하였고, 자연산 볼락이 71 개체 채집되어 전체 채집개체수의 $10.1 \%$ 를 차지하였다. 따라서 이번 조사 결과를 통해서 방류산 볼락이 방류에 의한 영향으로 자연산 볼락에 비하여 채집량이 많아진 것으로 생각되며, 방류 산 볼락의 경우 방류 10 일째에 68 개체, 20 일 째에 12 개체, 30 일 째에 24개체, 60 일 째에 34개체, 그리고 90일 째에는 36개체가 채집되어, 시간이 갈수록 채집 개체수가 다소 줄어들었다. 한 편, 자연산 볼락은 조사기간 동안 방류 후 10 일 째에 24 개체가
채집되었으며, 그 이후에는 3-4개체만이 채집되다가, 90일째 에 37 개체가 채집되었다.

진해만 잠도 주변해역에서 방류산 볼락이 자연산 방류 볼락 보다 많은 개체수가 채집되었으며, 방류 초기에 방류산 볼락 이 많이 채집되고 이후에는 다소 감소하는 것으로 보고하여

Table 2. Number of individuals of fish species and released Sebastes inermis collected by pots in the study area

\begin{tabular}{|c|c|c|c|c|c|c|}
\hline \multirow[b]{2}{*}{ Scientific name } & \multicolumn{6}{|c|}{ Days after released } \\
\hline & $\begin{array}{c}10 \\
\text { days }\end{array}$ & $\begin{array}{c}20 \\
\text { days }\end{array}$ & $\begin{array}{c}30 \\
\text { days }\end{array}$ & $\begin{array}{c}60 \\
\text { days }\end{array}$ & $\begin{array}{c}90 \\
\text { days }\end{array}$ & Total \\
\hline Released Sebastes inermis & 68 & 12 & 24 & 34 & 36 & 174 \\
\hline Stephanolepis cirrhifer & 18 & 1 & 21 & 68 & 10 & 118 \\
\hline Haichoeres poecilopterus & 8 & 2 & 3 & 32 & 3 & 48 \\
\hline Sebastes inermis & 24 & & 3 & 7 & 37 & 71 \\
\hline Acanthopagrus schlegeli & 16 & & 5 & 13 & & 34 \\
\hline Haxagrammos otakii & 16 & 3 & & 12 & & 31 \\
\hline Takifugu niphobles & & 2 & 18 & 3 & & 23 \\
\hline Sebastes thompsoni & 4 & 2 & 12 & 4 & & 22 \\
\hline Neoditrema ransonneti & 18 & & 1 & & & 19 \\
\hline Lateolabrax japonicus & 14 & & 3 & 2 & & 19 \\
\hline Ditremma temmincki & 6 & 10 & & & 3 & 19 \\
\hline Sebastes longispinis & 10 & 6 & & & & 16 \\
\hline Conger myriaster & 12 & & & 4 & & 16 \\
\hline Oplegnathus fasciatus & 4 & 1 & 6 & 2 & & 13 \\
\hline Rudarius ercodes & 6 & & 3 & 3 & & 12 \\
\hline Haxagrammos agrammus & 4 & & & 6 & & 10 \\
\hline Thamnaconus modestus & & 1 & 5 & 3 & & 9 \\
\hline Pleuronectes yokohamae & & & & 7 & & 7 \\
\hline Apogon lineatus & & 6 & & & & 6 \\
\hline Pseudaesopia japonica & 4 & & 1 & 1 & & 6 \\
\hline Sebastes schlegeli & 2 & & & 3 & & 5 \\
\hline Parapercis sexfasciata & & 1 & 2 & 2 & & 5 \\
\hline Pseudoblennius cottoides & & & 3 & 2 & & 5 \\
\hline Hypodytes rubripinnis & & 1 & 1 & 2 & 1 & 5 \\
\hline Sillago japonica & & & & 3 & & 3 \\
\hline Epinephelus akaara & & & & 3 & & 3 \\
\hline Microcanthus strigatus & & & 2 & 1 & & 3 \\
\hline Lateolabrax maculatus & & & & 2 & & 2 \\
\hline Konosirus punctatus & & & & 2 & & 2 \\
\hline Trachrus japonicus & & & & 2 & & 2 \\
\hline Paralichthys olivaceus & & & & 2 & & 2 \\
\hline Repomucenus beniteguri & & & & 2 & & 2 \\
\hline Pleuronectes herzensteini & & & & 1 & & 1 \\
\hline Scorpaenodes littoralis & & & & 1 & & 1 \\
\hline Chirolophis wui & & & & 1 & & 1 \\
\hline Platycephalus indicus & & & & 1 & & 1 \\
\hline Mugil cephalus & & & & 1 & & 1 \\
\hline Istigobius hoshinonis & & & 1 & & & 1 \\
\hline Pseudolabrus eoethinus & & & 1 & & & 1 \\
\hline Petroscirtes breviceps & & & & 1 & & 1 \\
\hline Siganus fuscescens & & & & 1 & & 1 \\
\hline Parupeneus ciliatus & & & & 1 & & 1 \\
\hline Helicolenus hilgendorfi & & & & 1 & & 1 \\
\hline Total & 234 & 48 & 115 & 236 & 90 & 722 \\
\hline
\end{tabular}


(NFRDI, 2007; Kim et al., 2009), 이번 조사 결과와 유사하였다. 또한 단각류를 주로 먹는 먹이습성, 공복율 및 위중량지수 등의 변화 양상도 유사하게 나타나 방류산 볼락의 서식 적응 능력은 해역에 관계없이 유사한 양상이었다. 지금까지 국내에 서 연구된 어류군집연구에서 볼락은 소형 빔트롤, 연안통발, 삼각망, 이각망, 저층자망 등 다양한 어구에 의해 채집되었다 (Huh and Kwak, 1997; Lee et al., 2000; An, 2002; Baeck et al., 2005; Jeong et al., 2005; Hong et al., 2008; Kwak et al., 2008). 그러나 볼락 유어의 경우 주로 잘피밭 (Eelgrass bed)에 서 소형 빔트롤, 그리고, 연안통발에서도 채집되었다 (Huh and Kwak, 1997; Lee et al., 2000; An, 2002; Beack et al., 2005; Jeong et al., 2005; Kwak et al., 2008). 본 조사해역과 같이 암반이 많이 분포하고 가두리 주변해역의 저질이 니질로 구성 되어 있는 해역에서는 소형 빔트롤에 의한 채집은 상당히 많은 어려움이 수반되므로, 암반지역에 서식하는 방류 볼락 유어의 채집에는 연안 통발이 가장 적합한 도구로 판단된다.

Table 3. The recapture individuals and percentage in released Sebastes inermis in the study area

\begin{tabular}{lccccccc}
\hline \multirow{2}{*}{ Items } & \multicolumn{6}{c}{ Day after released } \\
\cline { 2 - 8 } & $\begin{array}{l}10 \\
\text { days }\end{array}$ & $\begin{array}{c}20 \\
\text { days }\end{array}$ & $\begin{array}{c}30 \\
\text { days }\end{array}$ & $\begin{array}{c}60 \\
\text { days }\end{array}$ & $\begin{array}{c}90 \\
\text { days }\end{array}$ & Total \\
\hline Recapture individuals & 68 & 12 & 24 & 34 & 36 & 174 \\
Recapture percentage & 0.23 & 0.04 & 0.08 & 0.11 & 0.12 & 0.12 \\
Total & & & & & & 30,000 \\
\hline
\end{tabular}

방류개체수에 대한 방류산 볼락의 재채포율은 방류 10 일째 $0.23 \%$, 방류 20 일째 $0.04 \%$, 방류 30 일째 $0.08 \%$, 방류 60 일째에 는 $0.11 \%$, 그리고 방류 90 일째에는 $0.12 \%$ 를 나타내어 전체 약 $0.58 \%$ 를 나타내어 시간이 지남에 따라 감소하는 경향을 나타내었다 (Table 3).

방류산 볼락의 포식-피식관계

본 조사에서 수중비디오 및 연안통발 조사에 의한 결과와 방류지역과 인접한 남해도 주변해역에서 이전에 연구된 어류 군집연구 (Huh and Kwak, 1997; Kwak et al., 2008)를 토대로 방류산 볼락과 공존하면서 방류산 볼락을 섭식할 가능성이 있거나 실제로 볼락을 섭식한 어류를 살펴보면, 가시망둑 (Pseudoblennius cottoides), 고등어 (Scomber japonicus), 노래 미 (Hexagrammos agrammus), 농어 (Lateolabrax japonicus), 돌팍망둑 (Pseudoblennius percoides), 붕장어 (Conger myriaster), 양태 (Platycephalus indicus), 조피볼락 (Sebastes schlegeli), 쥐노래미 (Hexagrammos otakii), 흰꼬리볼락 (Sebastes longispinis) 등이 있었다. 상기의 어종 중 이미 식성이 보고된 가시망둑의 경우 전체 위내용물 중 어류가 차지하는 비율이 $48.1 \%$, 고등어는 $89.4 \%$, 노래미는 $5.6 \%$, 돌팍망둑은 $50.2 \%$, 붕장어는 $51.0 \%$, 양태는 $69.2 \%$, 조피볼락은 $96.3 \%$, 쥐노래미는 $19.2 \%$ 를 차지하였다 (Table 4). 특히 조피볼락은 실제로 볼락을 섭식하였으며, 위내용물 중 어류가 차지하는 비율이 가장 높아 방류 후 방류산 볼락을 가장 활발하게 섭식 할 것으로 판단된다 (Park et al., 2007). 한편 방류 볼락의 방류 시 함께 공존하고 있었던 고등어의 경우는 주 먹이생물이 멸치와 같은 표영성 어류로 암반 틈이나 아래에 숨어서 서식

Table 4. Review in feeding habits of piscivore in order to determine the degree of preyed released Sebastes inermis

\begin{tabular}{|c|c|c|c|c|}
\hline Scientific name & Main fish prey species & $\begin{array}{l}\text { dry weight } \\
\quad(\%)\end{array}$ & $\begin{array}{l}\text { Degree of preyed } \\
\text { released } \\
\text { Sebastes inermis }\end{array}$ & Reference \\
\hline Sebastes schlegeli & $\begin{array}{l}\text { Acanthopagrus schlegeli, Sebastes inermis, Engraulis japonicus, } \\
\text { Hypodytes rubripinnis, Sillago japonica }\end{array}$ & 96.3 & \multirow{3}{*}{ High } & Park et al. (2007) \\
\hline Lateolabrax japonicus & Fishes (E. japonicus etc.) & & & NFRDI (2004) \\
\hline Sebastes longispinis & Fishes & & & NFRDI (2004) \\
\hline Conger myriaster & $\begin{array}{l}\text { Favonigobius gymnauchen, Sillago japonica, Acentrogobius } \\
\text { pflaumi, Pholis nebulosa, Pseudoblennius cottoides, Syngnathus } \\
\text { schlegeli }\end{array}$ & 51.0 & \multirow{4}{*}{ Midium } & Huh and Kwak (1998a) \\
\hline $\begin{array}{l}\text { Pseudoblennius } \\
\text { percoides }\end{array}$ & Ditrema temmincki, S. schlegeli, Rudarius ercodes, P. cottoides & 50.2 & & Huh et al. (2008) \\
\hline $\begin{array}{l}\text { Pseudoblennius } \\
\text { cottoides }\end{array}$ & $\begin{array}{l}\text { F. gymnauchen, } P \text {. cottoides, A. pflaumi, C. myriaster, } P \text {. } \\
\text { nebulosa, S. schlegeli }\end{array}$ & 48.1 & & Huh and Kwak (1998b) \\
\hline Scomber japonicus & E. japonicus etc. & 89.4 & & Cha et al. (2004) \\
\hline $\begin{array}{l}\text { Hexagrammos } \\
\text { agrammus }\end{array}$ & P. nebulosa, $P$. cottoides & 5.6 & \multirow{3}{*}{ Low } & Kwak et al. (2005) \\
\hline Hexagrammos otakii & F. gymnauchen, P. nebulosa, A. pflaumi & 19.2 & & Kwak et al. (2005) \\
\hline Platycephalus indicus & F. gymnauchen, A. pflaumi & 69.2 & & Kwak and Huh (2002) \\
\hline
\end{tabular}


하는 볼락을 섭식할 가능성이 낮을 것으로 판단되지만 (Chaet al., 2004), 일정시간 계속 같은 해역에서 머무른다면 고등어에 의해 포식될 가능성도 배제할 수는 없다. 가시망둑과 돌팍망 둑의 경우 조피볼락이나 고등어에 비해 체장이 작지만, 위내 용물 중 어류가 차지하는 비율이 약 $50 \%$ 정도로 상당히 높은 값을 보였으며 (Huh and Kwak, 1998b; Huh et al., 2008), 실제로 수중잠수조사 결과 방류 후 볼락이 가시망둑에 의해 포식되는 것이 관찰되기도 하였다. 양태와 붕장어도 위내용물 중 어류 가 차지하는 비율이 각각 $51.0 \%$ 와 $69.2 \%$ 로 높은 값을 보여 방류산 볼락을 섭식할 가능성이 높은 어류임을 알 수 있었다. 그러나 양태의 경우 바닦에 붙어서 서식하는 특성을 가지고 있고 주 먹이생물이 날개망둑, 줄망둑과 같이 바닥에 붙어서 서식하는 망둥어과 어류로 나타나 방류산 볼락을 섭식할 가능 성이 그렇게 높지 않을 것으로 판단된다 (Huh and Kwak, 1998a; Kwak and Huh, 2002). 그리고 노래미와 쥐노래미의 경우 위내용물 중 어류가 차지하는 비율이 각각 $5.6 \%$ 와 $19.2 \%$ 로 낮게 나타났다 (Kwak et al., 2005). 노래미와 쥐노래미는 조사해역 주변에 많이 출현하는 어류이지만 다양한 먹이생물 을 섭식하는 잡식성 어류로 알려져 있어, 방류산 볼락을 선택 적으로 섭식하기 보다는 서식지 주변에 있는 방류산 볼락을 다른 먹이생물과 같이 섭식함을 알 수 있었다. 그 외 농어의 경우 다른 어류에 비해 비교적 체장이 크고 어류를 활발하게 섭식하는 것으로 알려져 있어 (NFRDI, 2004), 조피볼락과 비 슷하게 방류산 볼락을 포식할 것으로 판단된다. 흰꼬리볼락도 수중잠수조사에서 방류산 볼락을 포식하는 것이 발견되었으 나, 농어와 조피볼락에 비해 비교적 체장이 작고 조사해역에 서 출현량이 적어, 농어와 조피볼락에 비해서는 방류산 볼락 을 포식할 확률이 낮을 것으로 판단된다.

따라서 방류 지역에 출현하면서 방류산 볼락을 포식할 가능 성의 정도에 따라 높음 (high), 중간 (midium), 낮음 (low)으로 구분해 보면 (Table 4), 높음에는 농어와 조피볼락이 속하고, 중간에는 고등어, 흰꼬리볼락, 가시망둑, 돌팍망둑, 붕장어가 속하며, 그리고 낮음에는 노래미, 쥐노래미, 양태 등이 속하였다.

\section{사 사}

본 연구는 경상남도 위탁과제로 국립수산과학원 (RP-2010RE-004)에 의해 수행되었습니다.

\section{참고문헌}

An YR. 2002. Species composition and seasonal variation of fish assemblage in the Coastal Waster off Gadeok-do, Korea. Ph.D. Thesis, Pukyong Natl Univ 1-212.

Baeck GW, Kwak SN and Huh SH. 2005. Seasonal variation in abundance and species composition of fishes in an eelgrass bed in Myoungjuri of Jindong Bay. Kor J Ichthyol 17, 8-18.

Bailey KM and Houde ED. 1989. Predation on eggs and larvae of marine fishes and the recruitment problem. Adv Mar Biol 25, 1-83.

Cha BY, Gong YG, Lee CH and Kim DH. 2004. Feeding Ecology of pacific mackerel, Scomber japonicus, in Korean Waters. J Kor Fish Res 6, 14-22.

Cocheret de la Morinière E, Nagelkerken I, Meij H, Velde G. 2004. What attracts juvenile coral reef fish to mangroves: habitat complexity or shade? Mar Biol 144, 139.145.

Edgar GJ, Barrett NS and Morton AJ. 2004. Biases associated with the use of underwater visual census techniques to quantify the density and size-structure of fish populations. J Exp Mar Biol Ecol 308, 269-290.

Gamble JC and Hay SJ. 1989. Predation by the scyphomedusan Aurelia aurita on herring larvae in large enclosures: effects of predator size and prey starvation. Rapp. P. -V. Reun. -Cons. Inst Explor Mer, 191, 366-375.

Hong BK, Kim JS, Park KD, Jeon KA, Chun YY, Hwang KS, Kim YS and Park KY. 2008. Species composition of fish collected in gill net from Youngil Bay, East Sea of Korea. J Kor Fish Soc 41, 353-362.

Huh SH and Kwak SN. 1997. Species composition and seasonal variation of fishes in eelgrass bed (Zostera marina) bed in Kwangyang Bay. Kor J Ichthyol 9, 202-220.

Huh SH and Kwak SN. 1998a. Feeding habits of Conger myriaster in eelgrass bed (Zostera marina) bed in Kwangyang Bay. J Kor Fish Soc 31, 665-672.

Huh SH and Kwak SN. 1998b. Feeding habits of Pseudoblennius cottoides. J Kor Fish Soc 31, 37-44.

Huh SH, Kwak SN and Kim HW. 2008. Feeding habits of Pseudoblennius percoides (Pisces; Cottidae) in an eelgrass (Zoatera marina) bed of Dongdae Bay. Kor J Ichthyol 20, 45-53.

Jeong HH, Han KH, Kim CC, Yoon SM, Seo WI, Hwang SY and Lee SH. 2005. Fluctuations in abundance and species composition of fishes collected by both side fyke net in Dol-san, Yeosu. Kor J Ichthyol 17, 64-72.

Kim GS, Son MH, Kwak SN, Park JM, and Huh SH. 2009. Feeding habits of released black rockfish, Sebastes inermis, in coastal waters off Jam Island, Jinhae Bay, Korea. J Kor Fish Soc 42, 73-77.

Kwak SN and Huh SH. 2002. Feeding habits of Platycephalus indicus eelgrass (Zostera marina) bed in Kwangyang Bay. Kor J Ichthyol 14, 29-35.

Kwak SN Baeck GW and Huh SH. 2005. Comparative feeding ecology of two sympatric greenling species, 
Hexagrammos otakii and Hexagrammos agrammus in eelgrass Zostera marina beds. Environ Biol Fish 74, 129-140.

Kwak SN, Huh SH and Kim HW. 2008. Seasonal variation in species composition and abundance of fish assemblage in the coastal waters off Namhae Island. Kor J Ichthyol 20, 303-312.

Lee TW, Moon HT, Hwang HB, Huh SH and Kim DJ. 2000. Seasonal variation in species composition of fishes in the eelgrass beds in Angol Bay of the southern coast of Korea. J Kor Fish Soc 33, 439-447.

Masuda H, Amaoka K, Arago C, Ueno T and Yoshino T. 1984. The Fishes of the Japanese Archipelago, Tokai Univ. Press, Tokyo, Japan, 437+370 plates. Meynecke JO, Poole GC, Werry J and Lee SY. 2008. Use of PIT tag and underwater video recording in assessing estuarine fish movement in a high intertidal mangrove and salt marsh creek. Estuar Coast Shelf Sci 79, 168-178.

MOMAF. 2004. Studies on the Development of Marine Ranching Program in Tonyeong, Korea. MOMAF, Seoul, Korea, 1-1125.

MOMAF. 2006. Studies on the Development of Jeonnam Archipelago Marine Ranching Program in Korea. MOMAF, Seoul, Korea, 1-640.

NFRDI. 2004. Commercial Fishes of the Coastal \& Offshore Waters in Korea. Natl. Fish. Res. Dev. Inst., 1-333.

NFRDI. 2007. Effects of Released Fisheries Resources in 2007. 1-256.

Park KD, Kang YJ, Huh SH, Kwak SN, and Kim HW and Lee HW. 2007. Feeding ecology of Sebastes schlegeli in the Tongyeong Marine Ranching Area. J Kor Fish Soc 40, 308 314.

Samoilys MA. 1997. Underwater visual census surveys. In: Samoilys, M. (Ed.), Manual for Assessing Fish Stocks on Pacific Coral Reefs. Department of Primary Industries, Townsville, Australia.

Takeda M. 1982. Keys to Japanese and Foreign Cructaceans. Hokuryukan Press, Tokyo, Japan, 1-284.

Tanaka Y, Yamaguchi H, Tominaga O, Tsusaki $\mathrm{T}$ and Tanaka M. 2006. Relationships between release season and feeding performance of hatchery-reared Japanese flounder Paralichthys olivaceus: In situ release experiment in coastal area of Wakasa Bay, Sea of Japan. J Exp Mar Biol Ecol 330, 511-520.

Tessier E, Chabanet P, Pothin K, Soria M and Lasserre G. 2005. Visual censuses of tropical fish aggregations on artificial reefs: slate versus video recording techniques. J Exp Mar Biol Ecol 315, 17-30.

Yamashita Y, Nagahora S, Yamada H and Kitagawa D. 1994. Effects of release size on survival and growth of Japanese flounder Paralichthys olivaceus in coastal waters off Iwate Prefecture northern Japan. Mar Ecol Prog Ser 105, 269-276.

Yoon CH 2002. Fish of Korea with Pictorial Key and Systematic List. Academy Publ. Co. Seoul, Korea, $1-747$.

$\begin{array}{ll}\text { 2010년 } & \text { 3월 29일 접수 } \\ \text { 2010년 } & \text { 5월 17일 수정 } \\ \text { 2010년 } & \text { 6월 16일 수리 }\end{array}$

